\title{
Microstructure and Properties of Semi-Solid Aluminum Alloys: A Literature Review
}

\author{
Annalisa Pola ${ }^{1, * \mathbb{D}}$, Marialaura Tocci ${ }^{1}$ and Plato Kapranos ${ }^{2}$ \\ 1 DIMI-Mechanical and Industrial Engineering Department, Via Branze, 38-25123 Brescia, Italy; \\ m.tocci@unibs.it \\ 2 Department of Materials Science \& Engineering, The University of Sheffield, Sir Robert Hadfield Building, \\ Mappin Street, Sheffield S1 3JD, UK; p.kapranos@sheffield.ac.uk \\ * Correspondence: annalisa.pola@unibs.it; Tel.: +39-030-371-5576
}

Received: 4 February 2018; Accepted: 6 March 2018; Published: 13 March 2018

\begin{abstract}
Semi-solid processing of aluminum alloys is a well-known manufacturing technique able to combine high production rates with parts quality, resulting in high performance and reasonable component costs. The advantages offered by semi-solid processing are due to the shear thinning behavior of the thixotropic slurries during the mold filling. This is related to the microstructure of these slurries consisting of solid, nondendritic, near-globular primary particles surrounded by a liquid matrix. This paper presents a review on the formation of this nondendritic microstructure, reports on the different proposed mechanisms that might be responsible, and illustrates the relationship between microstructure and properties, in particular, tensility, fatigue, wear, and corrosion resistance.
\end{abstract}

Keywords: semi-solid; microstructure; mechanical properties; wear; corrosion

\section{Introduction}

Semi-solid metal (SSM) processing is a manufacturing technique where an alloy, in the form of a slurry of near-globular primary particles in a liquid matrix, is injected into a die, allowing the production of near-net-shape components. The main advantage of this technology is related to the flow properties of the metal in the form of a slurry, which, in the semi-solid state, is non-Newtonian and exhibits shear thinning behavior [1,2]. The viscosity of the SSM slurry is higher than when fully liquid, reducing the risk of turbulent [3] or spray flow, which is more typical of conventional pressure die-casting [3,4]. However, thanks to the shear thinning behavior of the slurry, under the influence of a shear force acting on it when it flows into the die, the viscosity decreases and the metal slurry is able to fill the cavity completely in a nonturbulent manner. As a consequence, semi-solid cast parts are almost free of gas porosity.

Injecting a partially solidified alloy slurry has the added benefit that shrinkage porosity is virtually absent [5]. The low or even absent porosity allows the production of structural parts with good mechanical properties that can also undergo subsequent heat treatments or welding operations.

Semi-solid processing guarantees higher performance than die-casting, while maintaining a number of the advantages of die-casting, such as good dimensional tolerances, high production rates, high surface quality, complex near-net-shape parts, and thin sections with very limited need of any finishing operations [6]. In addition, when compared to conventional die-casting, SSM processing increases die life because of the lower stress associated with the lower injection temperatures and speeds (i.e., lower mold attack and erosion, lower thermal shock), reduced cycle times and risk of hot tearing due to the lower temperature of the metal slurry (no over-heating), and associated lower energy consumption $[4,6,7]$.

On the other hand, SSM manufacturing requires specialized equipment for alloy preparation, combined with strict control of process parameters, particularly the alloy temperature, i.e., the solid/liquid 
fraction. Unfortunately, all these tend to increase the production costs [8], even though recent investigations have shown that SSM processing is only slightly more expensive than conventional die-casting and cheaper than some other competing foundry processes [9].

Since its development in the early 1970s at MIT [10], much research has been performed worldwide, aimed mainly at developing new and alternative routes of feedstock production for different alloys suitable for SSM processing. At present, there are a number of different techniques used to produce semi-solid castings, differentiated by the percentage of liquid/solid fraction they employ and the way they produce the alloy in the semi-solid state. SSM methods can be divided in two main categories according to their processing route, known as rheocasting and thixocasting [11]. In rheocasting, the semi-solid slurry is prepared in situ from the liquid state down to a certain percentage of solid fraction (usually between 10 and 30\% [12]), and then directly transferred into the shot sleeve for being injected into the die. In thixocasting, a billet, characterized by an almost globular or rosette-like microstructure developed through some specific route, is reheated in the mushy zone (semi-solid region) to an appropriately chosen solid fraction (usually between $50 \%$ and $60 \%$ [13]), placed in a modified shot sleeve and finally injected into the die [14]. Another classification methodology distinguishes the SSM methods according to the initial step used for obtaining the semi-solid feedstock, i.e., from the liquid state, by controlled solidification or from the solid state, via heavy plastic deformation and recrystallization [11].

Some of the most common routes for feedstock material preparation are: mechanical stirring, such as the SSR [15,16] or GISS [17] processes, electromagnetic stirring (EMS or MHD) [18,19], ultrasonic stirring (UTS) [20,21], New Rheocasting (NRC or UBE) [22,23], cooling slope [24], twin screw [25], Rheometal [26], liquid mixing method [27], SEED [28], thermomechanical [29], and SIMA $[14,30]$.

A number of interesting reviews about the different technologies available for obtaining nondendritic slurries can be found in the literature [11,13,14,31-33]. Nevertheless, independently from the chosen technique, the fundamental concept is based in developing feedstock with a microstructure of a solid, near-globular phase surrounded by a liquid matrix when in the semi-solid state. As already mentioned, when a shear stress is applied, the near-globular solid particles move easily between and over each other, reducing the viscosity and making the material behave like a liquid. On the contrary, when a shear stress is applied on a dendritic microstructure, the liquid remains entrapped between dendrite arms and prevents them from moving freely, thus increasing the viscosity of the alloy [32].

This paper presents a review on the formation of nondendritic microstructures, microstructures that have a key role in semi-solid processing, and discusses the different proposed mechanisms together with ways to analyze SSM microstructures. In addition, the review provides information on the variation of mechanical properties and corrosion behavior through modification of microstructures that are typical of SSM processing.

\section{Formation of Nondendritic Microstructures in SSM Processing}

During the early experiments performed by Spencer et al. on a Sn-Pb15 alloy [10], it was found that the microstructure of the material was strongly affected by the constant shearing of the alloy when in semi-solid state. Particularly, it was shown that shearing action causes the formation of a nondendritic grain structure, which is the distinctive characteristic of semi-solid alloys. Moreover, with further shearing during cooling, it is also possible to obtain spheroidal particles, typically with some entrapped liquid [4]. The authors also reported that high shear rates and slow cooling rates can promote the formation of spherical particles instead of rosette-like ones [10].

The steps for the formation of nondendritic microstructures have been extensively studied over the years and one of the first proposed mechanisms is shown in the schematic illustration of Figure 1. 


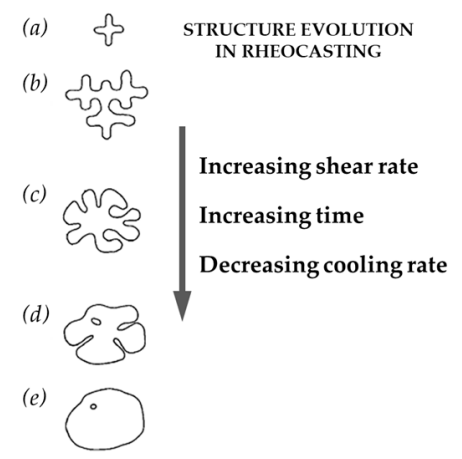

Figure 1. Globule formation during stirring in the semi-solid range: (a) initial dendritic fragment, (b) dendritic growth, $(\mathbf{c})$ rosette, $(\mathbf{d})$ ripened rosette, and (e) spheroid [4].

According to Flemings and co-workers [4], in the early stages of solidification, as it happens for all metallic materials, dendrites form in the liquid. However, unlike conventional solidification, the shearing action affects the dendritic morphology, which changes into that of a "rosette" due to different phenomena. Various explanations about the conversion mechanisms from dendritic to globular morphology can be found in the literature like ripening, shear, bending and abrasion with other growing crystals, dendrite fragmentation, remelting of dendrite arms, and growth control mechanisms [2]. Vogel et al. [34], for instance, proposed that under a shear force the dendrite arms bend plastically, thus introducing large misorientations into the arms and forming dislocations. At high temperatures these dislocations rearrange themselves inducing, under specific conditions, the detachment of dendrite arms [35] as shown in Figure 2. These dendrite fragments act as nuclei, coarsening and leading to the presence of globules of the primary phase $[4,35,36]$.

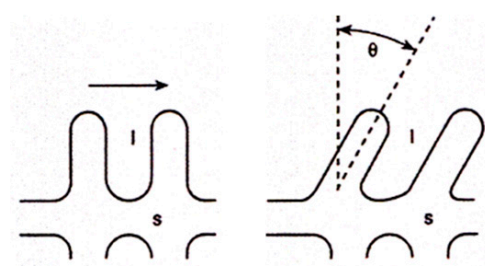

a) b)

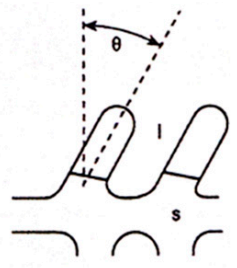

c)

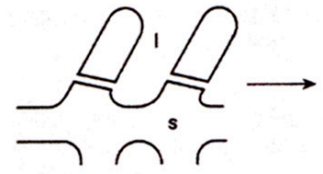

d)

Figure 2. Schematic model of fragmentation mechanism: (a) undeformed dendrite, (b) after bending, (c) dislocation rearrangement to give grain boundary, and (d) grain boundary wetting [35].

In contrast, Molennar et al. [37] proposed that rosette-like particles are the result of cellular growth. Mullis [38] reported that bending could bring about rosette formation without any need of mechanical effects due to shearing. According to Hellawell [39], the secondary dendrite arms can separate at their roots because of solute enrichment and thermosolutal convection that determines their remelting rather than breaking off for simple mechanical interactions (Figure 3). He suggested that in the solidification range, the solid is completely ductile and dendrites can be bent but not broken. Hence, the detachment of the secondary arms can be explained by a local remelting phenomenon. In particular, the remelting can occur either by recalescence of the whole system or by local recalescence due to fluctuations caused by convective phenomena or stirring $[14,40]$. 


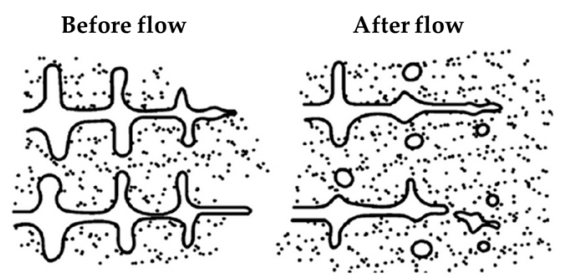

Figure 3. Schematic model of dendrite arms remelting [4].

The effect of the fluid flow characteristics on the morphology of solidification structures was also studied, by means of Monte Carlo simulation, by Das et al. [41]. They found that a rotational motion under laminar flow promotes rosette-like morphology due to a periodic stabilizing and destabilizing of the solid-liquid interface, while a turbulent flow hinders dendritic growth resulting in a compact morphology due to a stable solid-liquid interface. The presence of a concurrent mechanism was also proposed.

An interesting review of the various proposed mechanisms is reported in [2].

Figure 4 shows a typical microstructure of semi-solid castings, which consists of rosette-like or even globular grains (Figure 4a) and a dendritic structure typical of conventional casting processes (Figure 4b) [42].
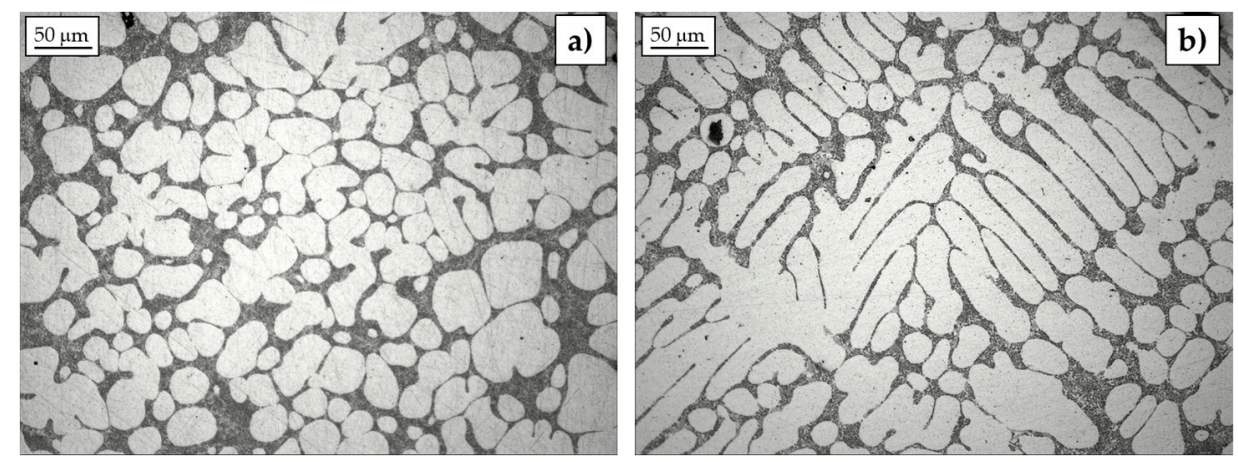

Figure 4. Typical microstructures of AlSi7 component (a) semi-solid cast and (b) conventionally cast.

\section{Microstructural Analysis of Semi-Solid Alloys}

In the analysis of microstructures of SSM components, dendrite arm spacing cannot be measured as in the case of conventional castings [43]; instead, the microstructural parameters taken into account are the size of the globules, their shape factor, i.e., their roundness, and the amount of entrapped liquid [44].

The globule size should be large enough to build an almost rigid solid phase network and, at the same time, small enough that the slurry can flow into the die cavity similarly to a liquid. The dimensions of the globules are usually defined as their mean diameters. It is typically assumed that the minimum thickness that can be filled by SSM should not be lower than 20-30 times the grain radius [11]. In particular, according to some findings, the optimum primary particle size for SSM alloys is lower than $100 \mu \mathrm{m}$ [45]. However, the grain size distribution measured by $2 \mathrm{D}$ analysis is difficult to determine and sometimes an extensive analysis of serial sections is needed to guarantee reliable data. A more accurate and consistent analysis of the grain size distribution and evolution can be performed via 3D examination methods, like X-ray microtomography [46-50], as shown in Figure 5. 


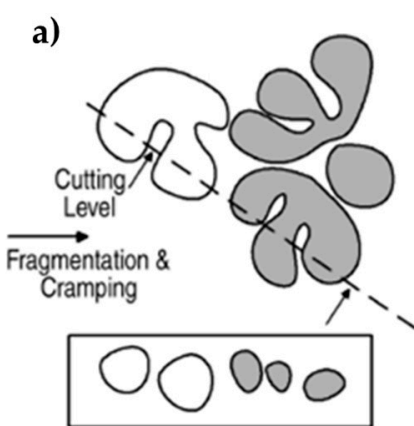

2-D Polished and Polarized
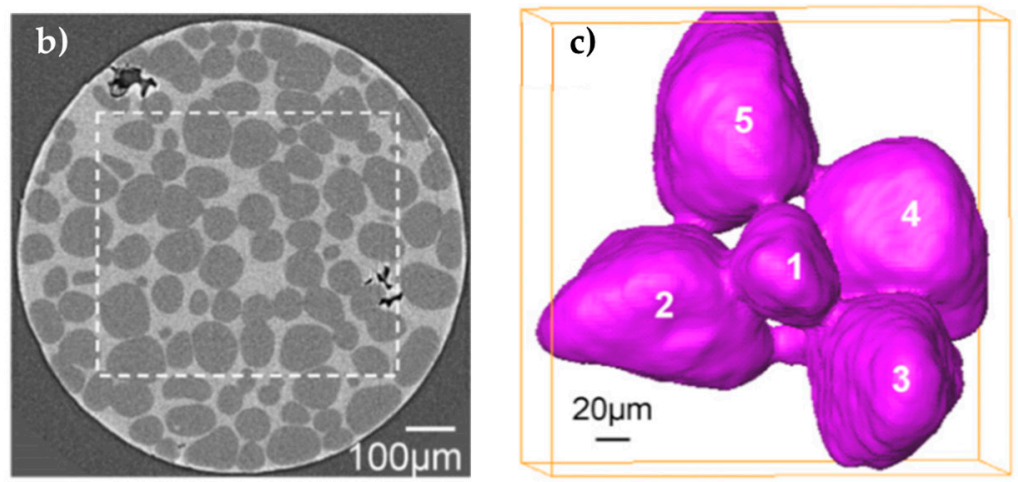

Figure 5. (a) Schematic representation of 2D analysis [50], (b) 3D image processing with 2D slice, and (c) volume representation of the acquired tomography data [51].

The shape factor is known to strongly affect the slurry viscosity. For laminar die filling in particular, the solid particles should preferably be round and separated from each other [11]. The shape factor $(F)$ is defined as:

$$
F=4 \pi A / P^{2}
$$

where $A$ is the area and $P$ is the perimeter of the particles.

A shape factor equal to 1 represents the case of a perfect circle and it reduces to zero with an increasing amount of irregularity, i.e., highly branched or elongated microstructures. In semi-solid processing, a shape factor above 0.6 is considered as appropriate [44]. Because the SSM particles can have complex morphologies, care should be taken when interpreting metallographic sections, as errors can arise if isolated secondary branches are taken into account as real single particles [52]. Thus, in order to obtain more reliable results, a high number of particles have to be measured.

The entrapped liquid is a distinct feature of the thixocasting route $[11,53]$. This liquid, as shown in Figure 6, does not contribute to the sliding of the globules during processing. Therefore, it follows that the liquid fraction is lower than the theoretical one and that the viscosity increases during die filling due to a sponge effect that can be induced [11]. The amount of entrapped liquid can be estimated by image analysis of 2D polished section areas, however, as in the case of the shape factor and globule size, errors can be introduced when some of the entrapped liquid islands appear to be isolated even though they are connected to the liquid phase at deeper levels. A more thorough investigation by means of 3D analysis allows more reliable data to be obtained.

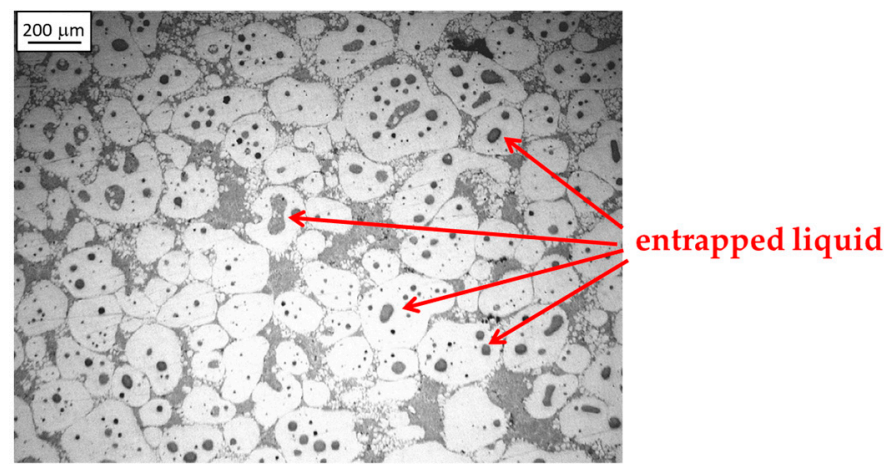

Figure 6. Thixocasting microstructure with entrapped liquid in the globules.

Clearly, different production routes of semi-solid parts can result in different microstructures, from rosette-like to near globular and details about them can be easily found in the literature [2,14]. 


\section{Performance of Semi-Solid Aluminum Alloys}

In recent years, several studies have been focused on the mechanical properties of parts fabricated by semi-solid/thixoforming processes, often in comparison to conventional routes.

\subsection{Mechanical Properties}

$\mathrm{Al}$ alloys are widely used in semi-solid processing as discussed in the previous section. The proven better quality of components obtained by SSM processes, and associated better properties, are often cited in textbooks about the topic $[11,13]$, in particular highlighting the possibility to perform T6 heat-treatment to further increase their characteristics. There are also many scientific studies on the mechanical properties of Al SSM alloys (both casting and wrought ones), even though significantly less than those on microstructural modification in comparison with conventional casting alloys.

\subsubsection{Tensile Behavior}

Since the very first production attempts, it was evident that semi-solid parts have high mechanical properties comparable to those of the forged material and better than permanent mold castings [4]. Over the years, these findings have been confirmed by many authors. In fact, the enhancement in performance of parts manufactured by SSM processing compared to traditionally cast parts is supported by various studies mainly on Al-Si [54-59], Al-Cu [60,61], and Al-Zn alloy families [62,63].

Bergsma et al. [64], for instance, reported that the tensile strength of 357 and modified 319 semi-solid formed aluminum alloys are superior to conventionally cast alloys due to the reduction in porosity and the spherical microstructure, when an effective optimization of heat treatment parameters is achieved. Cerri et al. [65] showed excellent ultimate tensile strength and yield strength of 319 alloy after appropriate heat treatment, in the order of $350 \mathrm{MPa}$ and $280 \mathrm{MPa}$, respectively, thus almost $100 \mathrm{MPa}$ higher than the conventionally cast counterparts. Similarly, Zhu et al. [66] analyzed different casting and forging alloys used industrially for the production of compressor wheels, finding that strength and ductility approach those of the forged components after T61 heat treatment, as shown in Figure 7. Nevertheless, in their work, the influence of microstructural features is not thoroughly investigated.

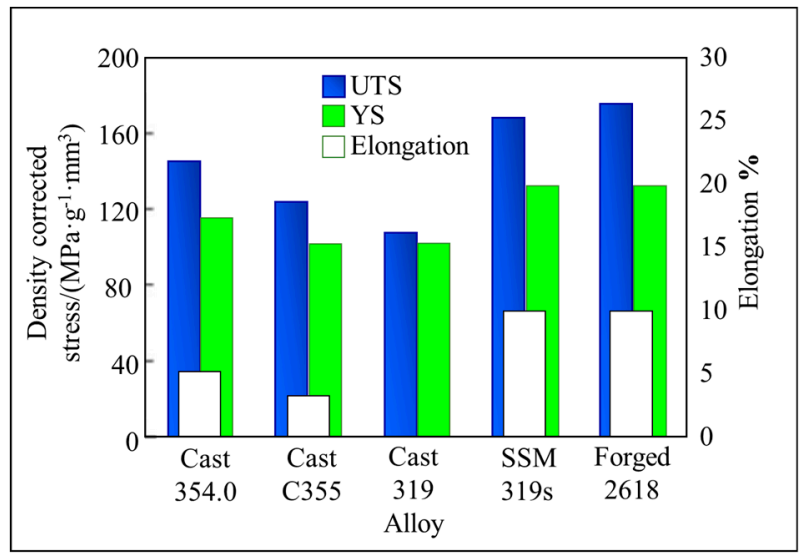

Figure 7. SSM 319 vs. cast C355, 354.0, 319 alloys and forged 2618 alloy after T61 heat treatment [66].

On the contrary, Haga et al. [67] discussed the influence of the size of primary globules on tensile properties of semi-solid castings. They underlined that the remarkable tensile properties are due not only to the nondendritic microstructure, but also to the small size of the primary $\alpha-\mathrm{Al}$, which is especially effective in enhancing the elongation to fracture. In particular, for the A356, the elongation can reach up to $18 \%$ by using the cooling slope method. 
Another study on an Al-Si-Mg-Fe alloy demonstrated the influence of the shape of primary $\alpha$-Al globules on ultimate tensile strength and elongation [68], a fact that is shown in Figure 8, i.e., when the shape factor increases (the more rounded the primary globules), tensile and elongation properties also increase.

Lü et al., investigating the behavior of rheocast 5052 alloy in comparison with gravity (GC) and high pressure (HPDC) die casting [69], noticed that fine and uniform microstructure throughout the entire SSM sample would effectively reduce stress concentrations at the grain boundaries under applied stress. They concluded that the globular shape is effective in enhancing the tensile strength and ductility, as detectable by fractographic analyses that show an almost ductile fracture mode for the rheocast alloy instead of the mixed ductile brittle fracture experienced by the gravity cast samples and with smaller dimples than those on the conventional casting sample (Figure 9).

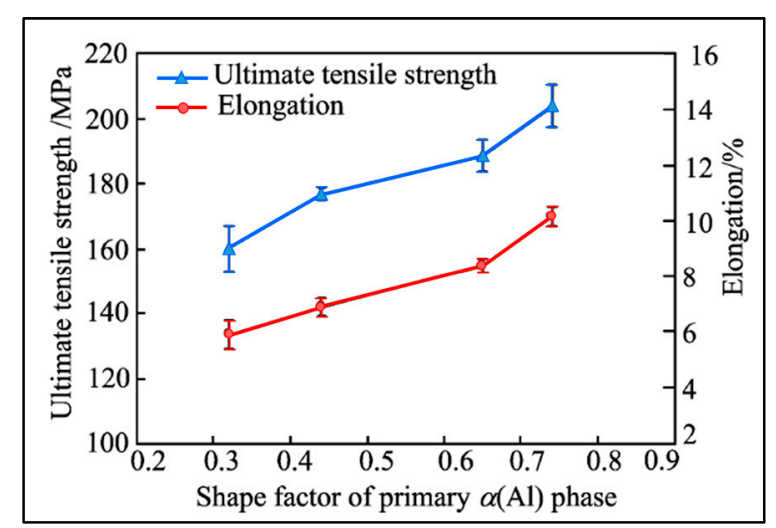

Figure 8. Effect of shape factor of primary $\alpha-\mathrm{Al}$ phase on ultimate tensile strength and elongation of semi-solid slurry for Al-Si-Mg-Fe alloy in as-cast condition [68].
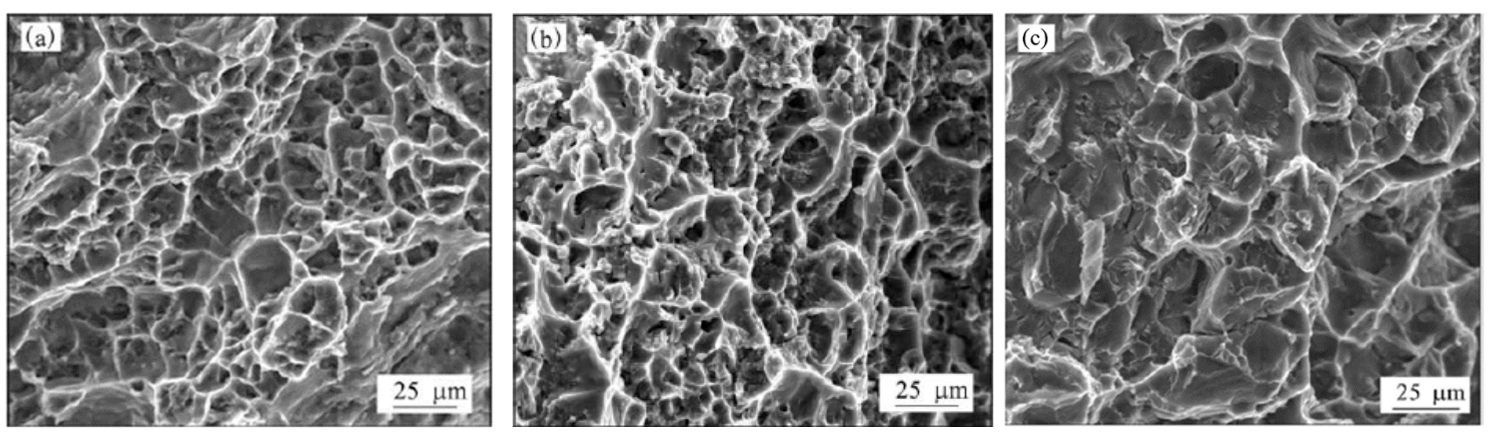

Figure 9. SEM micrographs of tensile fracture for samples produced under different processing conditions: (a) Rheo-HPDC; (b) conventional HPDC, and (c) conventional GC [69].

In Figure 10a, the comparison between the properties of semi-solid, casting, and forging Al-Si alloys summarized by Brochu et al. [70] is shown, further supporting the above-mentioned advantages. Clearly, different SSM process routes can result in different mechanical properties, as shown in Figure 10b [71]. However, the improved trend, as compared to traditional casting process, appears to hold in all cases as a consequence of the higher soundness of the components and the enhanced microstructure of semi-solid alloys, as discussed above. 

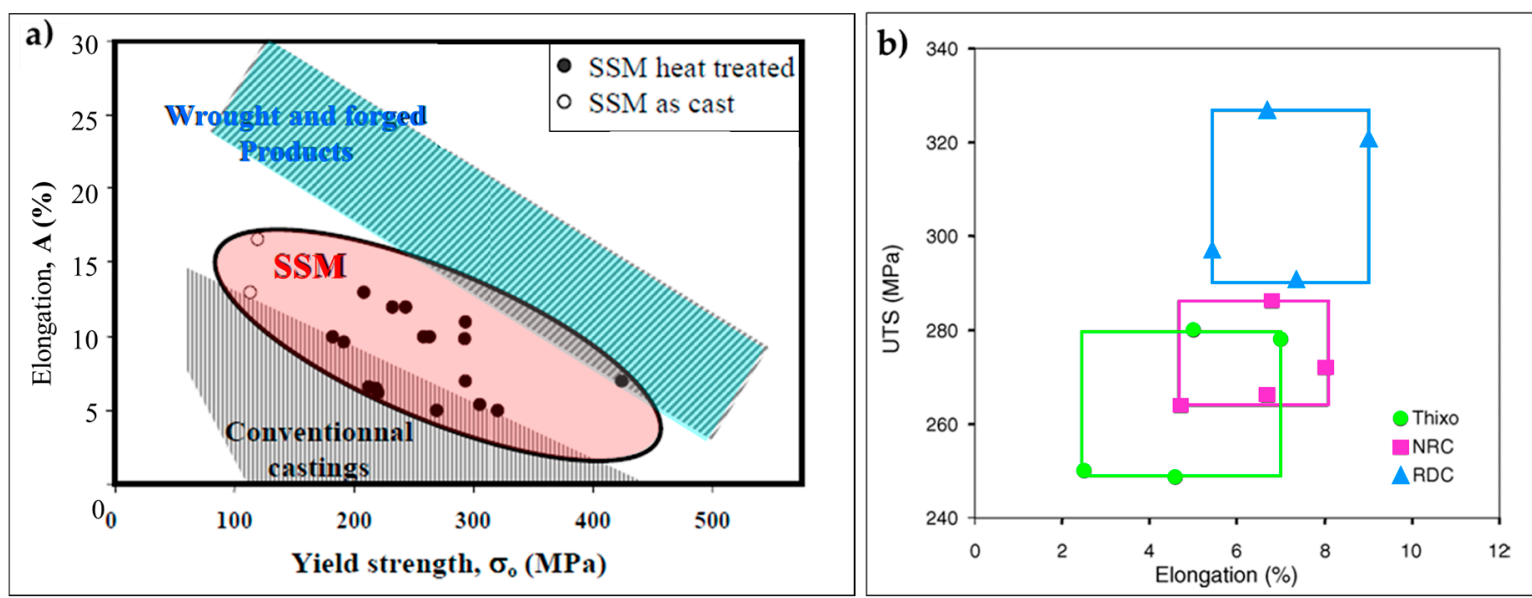

Figure 10. (a) Mechanical properties of SSM, cast and forged aluminum alloys [70] and (b) comparison of mechanical properties of A357 alloy under T5 condition obtained from different processing technologies [71].

Apart from the influence of primary $\alpha$-Al grains, the effect of different alloying elements, as well as the influence of secondary phases in SSM alloys, were examined. For example, the addition of Si and Fe in a 206 aluminum alloy for an automotive application was investigated by Lemieux et al. [72], who found remarkable performance of the tested rheocast components.

The influence of a significantly higher Si content (approximately $20 \mathrm{wt}$. \%) was examined in some studies, like that on a rheocast $\mathrm{Al}-\mathrm{Si}-\mathrm{Cu}$ alloy [73]. Recently, hypereutectic alloys processed by SSM methods have attracted the interest of researchers because of their heat-resistant properties. In hypereutectic Al-Si alloys, primary Si grains solidify as coarse plate-like particles, which can be refined by SSM processing, thus improving tensile properties, as demonstrated by Zheng et al. [74] studying the properties of AlSi30 rheo-diecast (RDC) compared to conventional die-casting. They pointed out that the UTS, elongation, and hardness of the SSM samples are approximately $57.9 \%, 42.9 \%$, and $20.6 \%$ higher than those of the die-casting ones, respectively. They attributed this to the finer compact primary Si grains, which can reduce or even eliminate crack initiation, combined with reduced porosity. The development of a series of hypereutectic alloys based on the A390 composition ( $17 \% \mathrm{Si}, 5 \% \mathrm{Cu}, 0.5 \%$ $\mathrm{Mg}$ ) and their thixoforming, have already been described by Kapranos et al. [75], together with their resulting microstructures and mechanical properties. Again, the main advantages of thixoforming were related to the improved size and morphology of brittle Si particles in comparison with conventionally cast parts, in addition to the expected spheroidisation of the Al matrix. The successful thixoforming of an automotive brake drum was reported and represented an interesting example of substitution of a conventional cast iron part with an aluminum one.

Concerning the effect of secondary phases (i.e., iron intermetallic compounds), interesting analyses can be found in the work of Shabestari et al. [56]. This is particularly interesting since numerous studies have reported the correlation between amount and morphology of secondary phases, for instance, intermetallic ones containing $\mathrm{Fe}, \mathrm{Mn}, \mathrm{Cr}, \mathrm{Ni}$, and mechanical properties [76-80] for casting Al-Si alloys. In particular, these authors found that the peculiar microstructural characteristics of the thixoformed alloy, such as the extremely low porosity, fine and equiaxed morphology of the $\alpha$-Al grains and uniform distribution of intermetallic compounds fragmented by the process route, enhance strength and elongation, in comparison with the as-cast condition. A similar topic was also discussed by Möller et al. [81] in a study of the microstructural and tensile properties of semi-solid metal high pressure die cast F357 alloy with various additions of $\mathrm{Fe}, \mathrm{Ni}$, and $\mathrm{Cr}$. In this case, the formation of intermetallic phases containing Fe and $\mathrm{Ni}$ lead to a decrease in strength and ductility due to their microcracking during tensile tests. 
Nowadays, the attention of the researchers is focused on the investigation of the properties of less conventional alloys for SSM processing, like AlSi8 [82], Al5Fe4Cu [83], $\mathrm{Al}-\mathrm{Zn}-\mathrm{Mg}-\mathrm{Cu}$ [84], $\mathrm{AlZnMg}$ alloys with Sc addition [85], etc., in order to evaluate the advantages in their application as semi-solid manufactured products.

\subsubsection{Fatigue Behavior}

Different researchers have compared high cycle fatigue resistance of SSM alloys (mainly based on $\mathrm{Al}-\mathrm{Si}$ ) with that of conventional casting ones [64,70,86-97]. There is a general consensus in these papers that the SSM samples show higher fatigue resistance, even though the data about the high cycles fatigue strength results is quite scattered (ranging from 60 to $180 \mathrm{MPa}$ ) depending on the process route used, casting and heat treatment parameters, as well as the possible presence of defects. The authors agree that the superior fatigue performance of SSM parts is related to the fact that they are almost free from defects like gas and shrinkage porosity as well as oxide inclusions. Thus, in defect-free parts, the microstructural constituents play a key role in fatigue crack nucleation and propagation [98]. As reported in $[70,99]$, for instance, a high volume fraction of primary $\alpha$-phase significantly increases the resistance to crack initiation. In particular, Park et al. found that fatigue cracks propagate mainly by cutting through the primary $\alpha$-phase when a low volume fraction of $\alpha$-phase is present; on the contrary, when the volume fraction is high, they mainly bypass the primary $\alpha$-phase following the phase boundaries [87].

Other reasons for fatigue improvements seem to be the smaller globule size as well as the finer size and distribution of eutectic Si particles of SSM castings [100]. Relating to the former, it is reported that fatigue strength increases with decreasing primary $\alpha$-phase size and that also, the globular morphology plays a positive role [70,86]. Additionally, the level of $\alpha$ globules agglomeration, which determines the size and distribution of Al-Si eutectic regions, influences the fatigue crack threshold. Concerning the Si particles, their interface with the $\alpha$-phase in the eutectic can act as nucleation point of fatigue cracks because of the mismatch of plastic deformation between each other that causes fracture and/or decohesion of Si lamellae. It follows that their more uniform distribution and fine size improve fatigue crack initiation resistance, as documented by different authors [70,87].

Ragab et al. [89] showed that grain boundaries in SSM microstructures act as a barrier to propagation of short cracks. Additionally, they provide evidence that fatigue failure is also associated with the presence of oxides as well as slip bands and intermetallic phases. Clearly, as in the case of conventional casting, with the presence of platelet-like and needle-like shapes, Fe-rich intermetallic compounds reduce the fatigue properties, as their morphology is conducive to high stress concentrations, thus making them a source of cracks able to cause failure [95]. Figure 11 shows an example of a fatigue fracture surface [95]. A mixed fracture mode can be clearly seen with both cleavage cracks, which induce brittle fracture, and dimples in the $\alpha$-phase, which denote a ductile fracture.
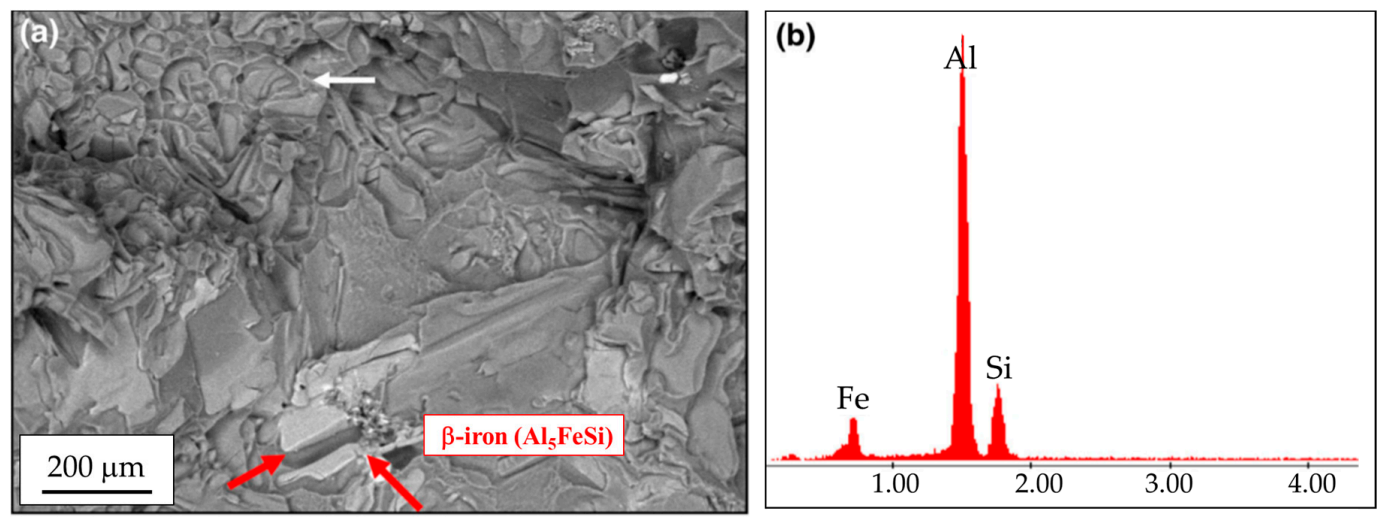

Figure 11. Scanning electron microscope analysis of the fatigue fracture surface of SSM A357 samples after T6 treatment [95]. 
It is known that iron up to $1.20 \%$ is needed in conventional die-casting to prevent alloy sticking onto die surfaces at high temperatures due to chemical, metallurgical, and mechanical interactions [101]. Interestingly, $\mathrm{Al}$ alloys for SSM contain lower amounts of Fe than conventional alloys for die-casting due to the reduced risk of die soldering related to the lower injection temperatures and speeds used during the process.

\subsection{Wear Resistance}

Regarding wear resistance, the dry sliding behavior of some SSM alloys has been evaluated in comparison with conventionally cast parts. Dey et al. show that the globular microstructures of A356 alloy castings appeared beneficial for dry wear resistance, as compared to dendritic ones [102]. In particular, the results of friction coefficients of SSM samples were lower than that of conventional cast specimens for all loads. The same holds for the wear loss.

A remarkable improvement in wear resistance of semi-solid specimens in comparison with conventional castings is also reported by Bayoumi et al. [103], who measured a lower wear rate for semi-solid processed A356 alloy. On the other hand, a comparable erosion mechanism was observed. Concurring results were found by other authors. The results from another study on the tribological properties of A356 alloy [104] showed that, for all applied loads, heat treatment enhanced the alloy behavior, while improvements caused by thixocasting were not systematic, i.e., a lower friction coefficient was noticed just for lower specific loads. Overall better wear resistance of thixocast materials, as compared to the original alloy, was attributed mainly to the improved distribution and smaller size of Si particles.

Several hypereutectic Al-Si compositions have also been investigated. It is a known fact that the presence of hard Si particles distributed in the matrix induces an outstanding wear resistance. However, the presence of casting defects like porosity, typical of traditional foundry processes, reduces their performance. In this regard, SSM processes make these alloys promising candidates for heavy wear applications. Very interesting results were obtained with A390 SSM alloy [105].

Birol et al. stated that the enhanced wear performances of hypereutectic Al-Si alloys are linked to the uniform distribution of fine primary Si particles [106]. Thus, the combination of a favorable silicon dispersion and the better soundness induced by the semi-solid processing gives superior wear performance.

Likewise, other chemical compositions showed comparable results in terms of improved wear behavior $[63,107]$. Recent studies on A319 confirm that the uniform distribution of Si, the reduction in porosity level, and the different morphology, size, and distribution of intermetallic phases obtained by SSM processing are responsible for better wear behavior than conventionally cast samples, even though the predominant wear mechanism remains the same for both the alloys [108,109].

Other damaging mechanisms of SSM components have been investigated over the years, such as cavitation resistance $[110,111]$. It was reported that the globular microstructure, as obtained by ultrasound treatment methods (UTS), increases the cavitation erosion resistance of the alloy because of the higher chemical and microstructural homogeneity, the morphology of the primary particles, and the refined structure of the eutectic due to the treatment itself. A comparison of the eroded area, at macroscopic scale, of conventionally cast (NUST) and SSM (UST) Al-Si7 samples is shown in Figure 12. It can be clearly seen that the highest damage was experienced by the conventionally cast alloy in the as-cast condition (Figure 12a), whereas the highest erosion resistance was exhibited by the heat-treated semi-solid sample (Figure 12d). 

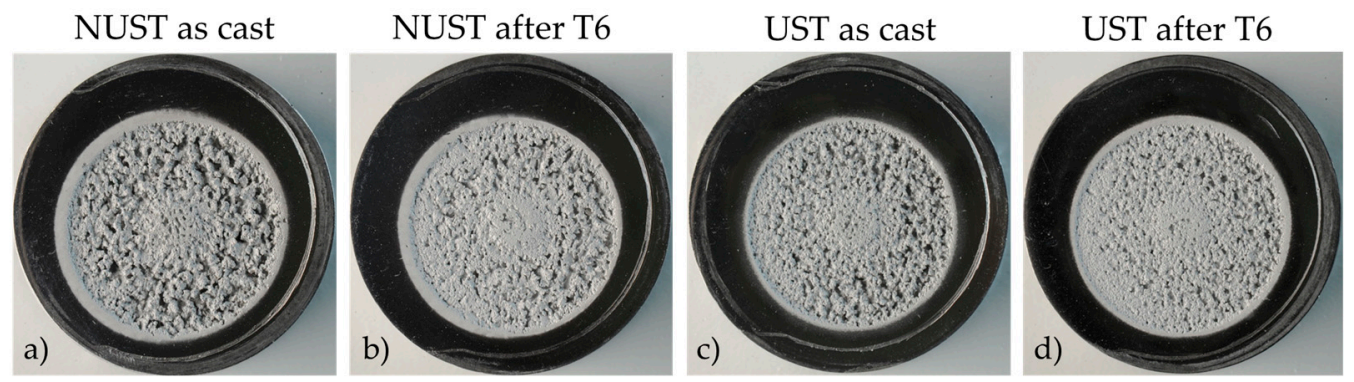

Figure 12. Surface topographies of the damaged areas of conventionally as-cast (a) before and (b) after T6, semi-solid in (c) as-cast and (d) after T6 [111].

\subsection{Corrosion Resistance}

Corrosion behavior of SSM aluminum alloys has not been explored to the same extent as mechanical performance and investigations on this property are more recent. For instance, Bastidas et al. [112] studied the pitting corrosion of A357 rheocast alloy, showing that it preferentially moves through the eutectic regions due to the Si particles that play a remarkable role in the corrosion process and to the cathodic properties of the intermetallic compounds.

A comparison between SSM and permanent mold cast A357 alloy was studied by Yu et al., who showed that both the resistance to corrosion and stress corrosion cracking is higher for semi-solid microstructures [97]. Similar results were obtained by other authors when comparing A356 semi-solid and low-pressure die-cast components. They highlighted that the number of pits and the degree of corrosion is higher for the conventionally cast products than in rheocast ones [99]. Similarly, Arrabal et al. [113] provide evidence about the better resistance of SSM as compared to gravity cast A356 alloy, as detectable by its lower cathodic current densities (Figure 13).

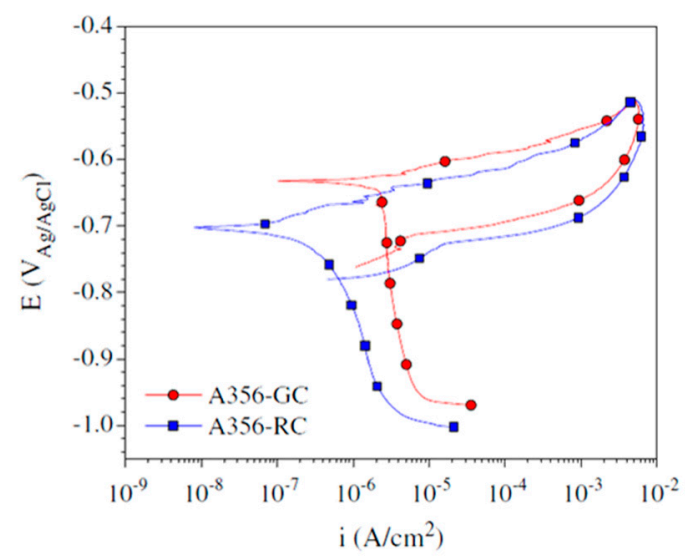

Figure 13. Cathodic polarisation curves of (a) gravity cast (GC) and (b) SSM (RC) A356 alloy after $1 \mathrm{~h}$ immersion in $3.5 \mathrm{wt}$. \% NaCl naturally-aerated solution [113].

The improved corrosion resistance of the SSM Al-Si alloys is related to the reduced area ratio between Si particles and $\alpha$-phase lamellae in the eutectic compared to that of their traditionally cast counterparts $[99,114,115]$. In particular, the differences in Si particle size and shape and, consequently, in the area ratio between silicon and $\alpha$-phase in the eutectic, are related to the different solidification rates combined with the different applied pressures during the casting processes [114].

Analyzing the damage by scanning electron microscopy, it is noted that the $\alpha$ globules appear almost not to have been attacked, while the Si particles and the intermetallic compounds in the eutectic have a fundamental role in the corrosion damage [113,116], acting as local cathodes (Figure 14). 


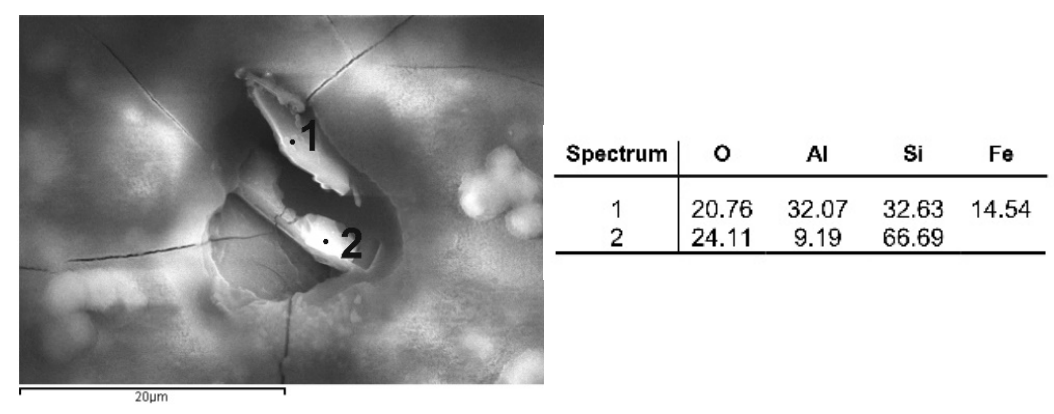

Figure 14. Cathodic effect of silicon and intermetallic particles [116].

Interestingly, some authors have also investigated the effect of surface eutectic segregation on corrosion resistance $[117,118]$. This thin layer of liquid phase can be found in semi-solid products due to the "sponge" effect [11], when the slurry is injected under pressure into the die, and it contains a higher amount of alloying elements than the bulk. Because, as reported above, the pitting corrosion in Al-Si alloys occurs preferentially in the eutectic area, the semi-solid parts characterized by the presence of this segregation layer are more prone to the phenomenon. Recently, 3D SEM tomography showed that corrosion takes place more at the interface between $\alpha$-phase and Fe-rich intermetallics than at the eutectic Si ones [119].

Some investigations are also available in the literature about other $\mathrm{Cu}$-containing aluminum alloys for SSM processing. Again, the intermetallic compounds were shown to exhibit a cathodic behavior as compared to the $\alpha$-phase [120].

\section{Summary}

In the present review paper, the microstructural characteristics of various semi-solid $\mathrm{Al}$ alloys are thoroughly summarized, together with the description of the evolution of their typical nondendritic microstructure during solidification. Furthermore, the influence of microstructural features on mechanical properties is systematically analyzed. This is fundamental in order to understand the different performance of SSM parts in comparison with components obtained by conventional production routes. Apart from tensile properties, other important characteristics are also discussed in order to provide a complete overview of the performance of semi-solid $\mathrm{Al}$ alloys, such as fatigue behavior, wear, and corrosion resistance.

Conflicts of Interest: The authors declare no conflict of interest.

\section{References}

1. Koke, J.; Modigell, M. Flow behaviour of semi-solid metal alloys. J. Non-Newton. Fluid Mech. 2003, 112, 141-160. [CrossRef]

2. Fan, Z. Semisolid metal processing. Int. Mater. Rev. 2002, 47, 49-85. [CrossRef]

3. Modigell, M.; Koke, J. Rheological modelling on semi-solid metal alloys and simulation of thixocasting processes. J. Mater. Process. Technol. 2001, 111, 53-58. [CrossRef]

4. Flemings, M.C. Behavior of metal alloys in the semisolid state. Metall. Trans. A 1991, 22, 957-981. [CrossRef]

5. Kirkwood, D.H. Semisolid metal processing. Int. Mater. Rev. 1994, 39, 173-189. [CrossRef]

6. Kapranos, P.; Ward, P.J.; Atkinson, H.V.; Kirkwood, D.H. Near net shaping by semi-solid metal processing. Mater. Des. 2000, 21, 387-394. [CrossRef]

7. Kiuchi, M.; Kopp, R. Mushy/Semi-Solid Metal Forming Technology—Present and Future. CIRP Ann.-Manuf. Technol. 2002, 51, 653-670. [CrossRef]

8. Chiarmetta, G. Thixoforming of automobile components. In Proceedings of the Fourth International Conference on Semi-Solid Processing of Alloys and Composites, Sheffield, UK, 19-21 June 1996.

9. Midson, S.P. Industrial applications for aluminum semi-solid castings. Solid State Phenom. 2014, 217-218, 487-495. [CrossRef] 
10. Spencer, D.B.; Mehrabian, R.; Flemings, M.C. Rheological behavior of $\mathrm{Sn}-15$ pct Pb in the crystallization range. Metall. Trans. 1972, 3, 1925-1932. [CrossRef]

11. Hirt, G.; Kopp, R. Thixoforming: Semi-Solid Metal Processing; Wiley-VCH, Verlag GmbH \& Co. KGaA: Weinheim, Germany, 2008.

12. Midson, S. Rheocasting processes for semi-solid casting of aluminum alloys. Die Cast. Eng. 2006, 50, 48-51.

13. Kirkwood, D.H.; Suéry, M.; Kapranos, P.; Atkinson, H.; Young, K.P. Semi-Solid Processing of Alloys; Springer: Berlin, Germany, 2010.

14. Nafisi, S.; Ghomashchi, R. Semi-Solid Processing of Aluminum Alloys; Springer: Berlin, Germany, 2016.

15. Yurko, J.A.; Martinez, R.A.; Flemings, M.C. Commercial development of the semi-solid rheocasting. In Proceedings of the 22nd International Congress on The North American Die Casting Association (NADCA '03), Indianapolis, IN, USA, 15-18 September 2003.

16. Yurko, J.; Boni, R. Semi-solid rheocasting [SSR ${ }^{\mathrm{TM}}$ semi-solid rheocasting]. Metall. Ital. 2006, 98, 35-41.

17. Wannasin, J.; Martinez, R.A.; Flemings, M.C. A novel technique to produce metal slurries for semi-solid metal processing. Solid State Phenom. 2006, 116-117, 366-369. [CrossRef]

18. Niedermaier, F.; Langgartner, J.; Hirt, G.; Niedick, I. Horizontal continuous casting of SSM billets. In Proceedings of the Fifth International Conference on Semi-Solid Processing of Alloys and Composites, Golden, CO, USA, 23-25 June 1998.

19. Kenney, M.P.; Evans, G.M.; Farrior, C.P.; Kyonka, A.A.; Koch, K.P. Semisolid Metal Casting and Forging, Metal Handbook, Vol. 15, "Casting"; ASM Publication: Des Plaines, IL, USA, 2002.

20. Abramov, V.O.; Abramov, O.V.; Straumal, B.B.; Gust, W. Hypereutectic Al-Si based alloys with a thixotropic microstructure produced by ultrasonic treatment. Mater. Des. 1997, 18, 323-326. [CrossRef]

21. Pola, A.; Arrighini, A.; Roberti, R. Effect of ultrasounds treatment on alloys for semisolid application. Solid State Phenom. 2008, 141-143, 481-486. [CrossRef]

22. Giordano, P.; Chiarmetta, G. New rheocasting: A valid alternative to the traditional technologies for the production of automotive suspension parts. In Proceedings of the 8th International Conference on Semi-Solid Processing of Alloys and Composites, S2P 2004, Limassol, Cyprus, 21-23 September 2004.

23. Cardoso, E.; Atkinson, H.V.; Jones, H. Microstructural evolution of A356 during NRC processing. In Proceedings of the 8th International Conference on Semi-Solid Processing of Alloys and Composites, S2P 2004, Limassol, Cyprus, 21-23 September 2004.

24. Haga, T.; Suzuki, S. Casting of aluminum alloy ingots for thixoforming using a cooling slope. J. Mater. Process. Technol. 2001, 118, 169-172. [CrossRef]

25. Fan, Z.; Bevis, M.J. Semi-solid processing of engineering alloys by a twin-screw rheomoulding process. Mater. Sci. Eng. A 2001, 299, 210-217. [CrossRef]

26. Granath, O.; Wessén, M.; Cao, H. Porosity reduction possibilities in commercial aluminium A380 and magnesium AM60 alloy components using the rheometal ${ }^{[\mathrm{тм}]}$ process. In Proceedings of the 4th International Conference High tech Die Casting, Brescia, Italy, 9-10 April 2008.

27. Findon, M.; de Figueredo, A.M.; Apelian, D.; Makhlouf, M.M. Melt mixing approaches for the formation of thixotropic semisolid metal structure. In Proceedings of the 7th International Conference on Semi-Solid Processing of Alloys and Composites, Tsukuba, Japan, 25-27 September 2002.

28. Langlais, J.; Lemieux, A. The SEED technology for semi-solid processing of aluminum alloys: A metallurgical and process overview. Solid State Phenom. 2006, 16, 472-477. [CrossRef]

29. Vieira, E.A.; Kliauga, A.M.; Ferrante, M. On the formation of spheroidal microstructures in a semi-solid Al-Si alloy by thermomechanical processing. Scr. Mater. 2007, 57, 1165-1168. [CrossRef]

30. Tzimas, E.; Zavaliangos, A. Evolution of near-equiaxed microstructure in the semisolid state. Mater. Sci. Eng. A 2000, 289, 228-240. [CrossRef]

31. Atkinson, H.V. Modelling the semisolid processing of metallic alloys. Prog. Mater. Sci. 2005, 50, $341-412$. [CrossRef]

32. Mohammed, M.N.; Omar, M.Z.; Salleh, M.S.; Alhawari, K.S.; Kapranos, P. Semisolid metal processing techniques for nondendritic feedstock production. Sci. World J. 2013, 2013, 752175. [CrossRef] [PubMed]

33. Nafisi, S.; Ghomashchi, R. Semi-solid metal processing routes: An overview. Can. Metall. Q. 2005, 44, $289-304$. [CrossRef] 
34. Vogel, A.; Doherty, R.D.; Cantor, B. Stir-cast microstructure and slow crack growth. In Solidification and Casting of Metals: Proceedings of an International Conference on Solidification; Metals Society: London, UK, 1979; p. 518.

35. Doherty, R.D.; Lee, H.-I.; Feest, E.A. Microstructure of stir-cast metals. Mater. Sci. Eng. 1984, 65, 181-189. [CrossRef]

36. Loué, W.R.; Suéry, M. Microstructural evolution during partial remelting of Al-Si7Mg alloys. Mater. Sci. Eng. A 1995, 203, 1-13. [CrossRef]

37. Molenaar, J.M.M.; Katgerman, L.; Kool, W.H.; Smeulders, R.J. On the formation of the stircast structure. J. Mater. Sci. 1986, 21, 389-394. [CrossRef]

38. Mullis, A.M. Growth induced dendritic bending and rosette formation during solidification in a shearing flow. Acta Mater. 1999, 47, 1783-1789. [CrossRef]

39. Hellawell, A. Grain evoluation in conventional rheocasting. In Proceedings of the 4th International Conference on Semi-Solid Processing of Alloys and Composites, Sheffield, UK, 19-21 June 1996.

40. Flemings, M.C.; Yurko, J.A.; Martinez, R.A. Solidification processes and microstructures. In Proceedings of the TMS Annual Meeting, Charlotte, NC, USA, 14-18 March 2004.

41. Das, A.; Ji, S.; Fan, Z. Morphological development of solidification structures under forced fluid flow: A Monte-Carlo simulation. Acta Mater. 2002, 50, 4571-4585. [CrossRef]

42. Pola, A.; Arrighini, A.; Roberti, R. Ultrasounds: A new technology for alloys degassing, grain refinement and obtainment of a thixotropic structure. In Proceedings of the International Conference on Aluminium Alloys (ICAA), Aachen, Germany, 22-26 September 2008.

43. Campbell, J. Castings; Butterworth-Heinemann: Oxford, UK, 2003; Chapter 9.

44. Kapranos, P.; Haga, T.; Bertoli, E.; Pola, A.; Azpilgain, Z.; Hurtado, I. Thixo-extrusion of 5182 aluminium alloy. Solid State Phenom. 2008, 141-143, 115-120. [CrossRef]

45. Apelian, D. Semi-Solid Processing Routes and Microstructure Evolution. In Proceedings of the Seventh International Conference titled Advanced Semi-Solid Processing of Alloys and Composites, Tsukuba, Japan, 24-28 September 2002; pp. 25-30.

46. Suery, M. Microstructure of semi-solid alloys and properties. In Proceedings of the 8th International Conference on Semi-Solid Processing of Alloys and Composites, S2P 2004, Limassol, Cyprus, 21-23 September 2004.

47. Suéry, M. Mise en Forme des Alliages Métalliques a l'État Semi Solide; Hermes Science Publications: Paris, France, 2002.

48. Terzi, S.; Salvo, L.; Suery, M.; Dahle, A.; Boller, E. In situ microtomography investigation of microstructural evolution in Al-Cu alloys during holding in semi-solid state. Trans. Nonfeer. Met. Soc. China 2010, 20, s734-s738. [CrossRef]

49. Modigell, M.; Pola, A.; Suéry, M.; Zang, C. Investigation of correlations between shear history and microstructure of semi-solid alloys. Solid State Phenom. 2013, 192-193, 251-256. [CrossRef]

50. Nafisi, S.; Ghomashchi, R. Combined grain refining and modification of conventional and rheo-cast A356 Al-Si alloy. Mater. Charact. 2006, 57, 371-385. [CrossRef]

51. Limodin, N.; Salvo, L.; Suéry, M.; DiMichiel, M. In situ investigation by X-ray tomography of the overall and local microstructural changes occurring during partial remelting of an Al-15.8 wt.\% Cu alloy. Acta Mater. 2007, 55, 3177-3191. [CrossRef]

52. Nafisi, S.; Ghomashchi, R. The microstructural characterization of semi-solid slurries. JOM 2006, 58, 24-30. [CrossRef]

53. Pola, A.; Roberti, R.; Frerini, F. Microstructure and mechanical behaviour of cast aluminium components obtained by thixocasting and traditional processes. In Proceedings of the 8th International Conference on Semi-Solid Processing of Alloys and Composites, S2P 2004, Limassol, Cyprus, 21-23 September 2004.

54. Chen, Z.; Mao, W.; Wu, Z. Mechanical properties and microstructures of Al alloy tensile samples produced by serpentine channel pouring rheo-diecasting process. Trans. Nonfeer. Met. Soc. 2011, 21, 1473-1479. [CrossRef]

55. Jamaati, R.; Amirkhanlou, S.; Toroghinejad, M.R.; Niroumand, B. Significant improvement of semi-solid microstructure and mechanical properties of A356 alloy by ARB process. Mater. Sci. Eng. A 2011, 528, 2495-2501. [CrossRef]

56. Shabestari, S.G.; Parshizfard, E. Effect of semi-solid forming on the microstructure and mechanical properties of the iron containing Al-Si alloys. J. Alloy. Compd. 2011, 509, 7973-7978. [CrossRef] 
57. Wu, S.; Lu, S.; An, P.; Nakae, H. Microstructure and property of rheocasting aluminum-alloy made with indirect ultrasonic vibration process. Mater. Lett. 2012, 73, 150-153. [CrossRef]

58. Zhao, J.-W.; Wu, S.S. Microstructure and mechanical properties of rheo-diecasted A390 alloy. Trans. Nonfeer. Met. Soc. 2010, 20, 754-757. [CrossRef]

59. Cerri, E.; Evangelista, E.; Spigarelli, S.; Cavaliere, P.; DeRiccardis, F. Effects of thermal treatments on microstructure and mechanical properties in a thixocast 319 aluminum alloy. Mater. Sci. Eng. A 2000, 284, 254-260. [CrossRef]

60. Dai, W.; Wu, S.; Lu, S.; Lin, C. Effects of rheo-squeeze casting parameters on microstructure and mechanical properties of AlCuMnTi alloy. Mater. Sci. Eng. A 2012, 538, 320-326. [CrossRef]

61. Jiang, H.; Lu, Y.; Huang, H.; Li, X.; Li, M. Microstructural evolution and mechanical properties of the semisolid Al-4Cu-Mg alloy. Mater. Charact. 2003, 51, 1-10.

62. Xu, C.; Zhao, J.; Guo, A.; Li, H.; Dai, G.; Zhang, X. Effects of injection velocity on microstructure, porosity and mechanical properties of a rheo-diecast Al-Zn-Mg-Cu aluminum alloy. J. Mater. Process. Technol. 2017, 249, 167-171. [CrossRef]

63. Alipour, M.; Aghdam, B.G.; Rahnoma, H.E.; Emamy, M. Investigation of the effect of Al-5Ti-1B grain refiner on dry sliding wear behavior of an $\mathrm{Al}-\mathrm{Zn}-\mathrm{Mg}-\mathrm{Cu}$ alloy formed by strain-induced melt activation process. Mater. Des. 2013, 46, 766-775. [CrossRef]

64. Bergsma, S.C.; Li, X.; Kassner, M.E. Semi-solid thermal transformations in Al-Si alloys: II. The optimized tensile and fatigue properties of semi-solid 357 and modified 319 aluminum alloys. Mater. Sci. Eng. A 2001, 297, 69-77. [CrossRef]

65. Cerri, E.; Cabibbo, M.; Cavaliere, P.; Evangelista, E. Mechanical behaviour of 319 heat treated thixo cast bars. Mater. Sci. Forum 2000, 331, 259-264. [CrossRef]

66. Zhu, Q.; Midson, S.P. Semi-solid moulding: Competition to cast and machine from forging in making automotive complex components. Trans. Nonfeer. Met. Soc. China 2010, 20, s1042-s1047. [CrossRef]

67. Haga, T.; Kapranos, P. Simple rheocasting processes. J. Mater. Process. Technol. 2002, 130-131, 594-598. [CrossRef]

68. Burapa, R.; Janudom, S.; Chucheep, T.; Canyook, R.; Wannasin, J. Effects of primary phase morphology on mechanical properties of Al-Si-Mg-Fe alloy in semi-solid slurry casting process. Trans. Nonfeer. Met. Soc. China 2010, 20, 857-861. [CrossRef]

69. Lu, S.; Wu, S.; Zhu, Z.; An, P.; Mao, Y. Effect of semi-solid processing on microstructure and mechanical properties of 5052 aluminum alloy. Trans. Nonfeer. Met. Soc. China 2010, 20, 758-762. [CrossRef]

70. Brochu, M.; Verreman, Y.; Ajersch, F.; Bucher, L. Fatigue Behavior of Semi-Solid Cast Aluminum: A Critical Review. Solid State Phenom. 2008, 141, 725-730. [CrossRef]

71. Fan, Z.; Fang, X.; Ji, S. Microstructure and mechanical properties of rheo-diecast (RDC) aluminium alloys. Mater. Sci. Eng. A 2005, 412, 298-306. [CrossRef]

72. Lemieux, A.; Langlais, J.; Bouchard, D.; Grant Chen, X. Effect of Si, Cu and Fe on mechanical properties of cast semi-solid 206 alloys. Trans. Nonfeer. Met. Soc. China 2010, 20, 1555-1560. [CrossRef]

73. Wu, S.; Zhong, G.; Wan, L.; An, P.; Mao, Y. Microstructure and properties of rheo-diecast Al-20Si-2Cu-1Ni-0.4Mg alloy with direct ultrasonic vibration process. Trans. Nonfeer. Met. Soc. China 2010, 20, 763-767. [CrossRef]

74. Zheng, Z.-K.; Ji, Y.-J.; Mao, W.-M.; Yue, R.; Liu, Z.-Y. Influence of rheo-diecasting processing parameters on microstructure and mechanical properties of hypereutectic Al-30\%Si alloy. Trans. Nonfeer. Met. Soc. China 2017, 27, 1264-1272. [CrossRef]

75. Kapranos, P.; Kirkwood, D.H.; Atkinson, H.V.; Rheinlander, J.T.; Bentzen, J.J.; Toft, P.T.; Debel, C.P.; Laslaz, G.; Maenner, L.; Blais, S.; et al. Thixoforming of an automotive part in A390 hypereutectic Al-Si alloy. J. Mater. Process. Technol. 2003, 135, 271-277. [CrossRef]

76. Taylor, J.A. Iron-containing intermetallic phases in Al-Si based casting alloys. Procedia Mater. Sci. 2012, 1, 19-33. [CrossRef]

77. Di Giovanni, M.T.; Cerri, E.; Casari, D.; Merlin, M.; Arnberg, L.; Garagnani, G.L. The Influence of Ni and V Trace Elements on High-Temperature Tensile Properties and Aging of A356 Aluminum Foundry Alloy. Metall. Mater. Trans. A 2016, 47, 2049-2057. [CrossRef]

78. Shabestari, S.G. The effect of iron and manganese on the formation of intermetallic compounds in aluminum-silicon alloys. Mater. Sci. Eng. A 2004, 383, 289-298. [CrossRef] 
79. Tocci, M.; Pola, A.; Raza, L.; Armellin, L.; Afeltra, U. Optimization of heat treatment parameters for a nonconventional Al-Si-Mg alloy with cr addition by DoE method. Metall. Ital. 2016, 108, 141-144.

80. Ceschini, L.; Boromei, I.; Morri, A.; Seifeddine, S.; Svensson, I.L. Effect of Fe content and microstructural features on the tensile and fatigue properties of the Al-Si10-Cu2 alloy. Mater. Des. 2012, 36, 522-528. [CrossRef]

81. Moller, H.; Stumpf, W.E.; Pistorius, P.C. Influence of elevated Fe, Ni and Cr levels on tensile properties of SSM-HPDC Al-Si-Mg alloy F357. Trans. Nonfeer. Met. Soc. China 2010, 20, 842-846. [CrossRef]

82. Qi, M.F.; Kang, Y.L.; Zhu, G.M. Microstructure and properties of rheo-HPDC Al-8Si alloy prepared by air-cooled stirring rod process. Trans. Nonfeer. Met. Soc. China 2017, 27, 1939-1946. [CrossRef]

83. Bo, L.; Jun, H.H.; Guang, Y.X. The heat treatment response of semisolid formed Al-5Fe-4Cu alloy. Philos. Mag. 2017, 98, 605-622. [CrossRef]

84. Chen, G.; Chen, Q.; Wang, B.; Du, Z.-M. Microstructure evolution and tensile mechanical properties of thixoformed high performance Al-Zn-Mg-Cu alloy. Met. Mater. Int. 2015, 21, 897-906. [CrossRef]

85. Zhao, J.; Xu, C.; Dai, G.; Wu, S.; Han, J. Microstructure and properties of rheo-diecasting wrought aluminum alloy with Sc additions. Mater. Lett. 2016, 173, 22-25. [CrossRef]

86. Hayat, N.; Toda, H.; Kobayashi, T.; Wade, N. Experimental investigations of fatigue characteristics of AC4CH cast aluminum alloys fabricated through rheocast and squeeze cast methods. Mater. Sci. Forum 2002, 396, 1353-1358. [CrossRef]

87. Park, C.; Kim, S.; Kwon, Y.; Lee, Y.; Lee, J. Fracture behavior of thixoformed 357-T5 Al alloys. Metall. Mater. Trans. A 2004, 35, 1017-1027. [CrossRef]

88. Davidson, C.J.; Griffiths, J.R.; Badiali, M.; Zanada, A. Fatigue properties of a semi-solid cast Al-7Si-0.3 Mg-T6 alloy. Metall. Sci. Technol. 2000, 18, 27-31.

89. Ragab, K.A.; Bouazara, M.; Bouaicha, A.; Mrad, H. Materials performance and design analysis of suspension lower-arm fabricated from Al-Si-Mg castings. Key Eng. Mater. 2016, 710, 315-320. [CrossRef]

90. Blad, M.; Johannesson, B.; Nordberg, P.; Winklhofer, J. Manufacturing and fatigue verification of two different components made by semi-solid processing of aluminium TX630 alloy. Solid State Phenom. 2016, 256, 328-333. [CrossRef]

91. Alain, A.A.; Myriam, B.; Heinrich, M. Effect of the rheocasting process and of the SLS layer on the fatigue behavior of 357 aluminum alloy. Solid State Phenom. 2014, 217, 227-234.

92. Gan, Y.X.; Overfelt, R.A. Fatigue property of semisolid A357 aluminum alloy under different heat treatment conditions. J. Mater. Sci. 2006, 41, 7537-7544. [CrossRef]

93. Rosso, M.; Peter, I.; Villa, R. Effects of T5 and T6 heat treatments applied to rheocast A356 parts for automotive applications. Solid State Phenom. 2008, 141, 237-242. [CrossRef]

94. Bergsma, S.C.; Kassner, M.E.; Evangelista, E.; Cerri, E. The optimized tensile and fatigue properties of electromagnetically stirred and thermally transformed semi-solid 357 and modified 319 aliminum alloys. In Proceedings of the 6th International Conference on Semi-Solid Processing of Alloys and Composites, S2P 2000, Turin, Italy, 27-29 September 2000; pp. 319-324.

95. Bouazara, M.; Bouaicha, A.; Ragab, K.A. Fatigue Characteristics and Quality Index of A357 Type Semi-Solid Aluminum Castings Used for Automotive Application. J. Mater. Eng. Perform. 2015, 24, 3084-3092. [CrossRef]

96. Ragab, K.A.; Bouazara, M.; Bouaicha, A.; Allaoui, O. Microstructural and mechanical features of aluminium semi-solid alloys made by rheocasting technique. Mater. Sci. Technol. (UK) 2017, 33, 646-655. [CrossRef]

97. Yu, Y.; Kim, S.; Lee, Y.; Lee, J. Phenomenological Observations on Mechanical and Corrosion Properties of Thixoformed 357 Alloys: A Comparison with Permanent Mold Cast 357 Alloys. Metall. Mater. Trans. A 2002, 33, 1339-1412. [CrossRef]

98. Brochu, M.; Verreman, Y.; Ajersch, F.; Bouchard, D. High cycle fatigue strength of permanent mold and rheocast aluminum 357 alloy. Int. J. Fatigue 2010, 32, 1233-1242. [CrossRef]

99. Park, C.; Kim, S.; Kwon, Y.; Lee, Y.; Lee, J. Mechanical and corrosion properties of rheocast and low-pressure cast A356-T6 alloy. Mater. Sci. Eng. A 2005, 391, 86-94. [CrossRef]

100. Lados, D.A.; Apelian, D. Fatigue crack growth mechanisms during dynamic loading of conventionally and SSM cast aluminum components. In Proceedings of the 8th International Conference on Semi-Solid Processing of Alloys and Composites, S2P 2004, Limassol, Cyprus, 21-23 September 2004; pp. 833-842.

101. Kaufman, G.; Rooy, E.L. Aluminum Alloy Castings Properties, Processes, and Applications; ASM International: Materials Park, OH, USA, 2004; p. 15. 
102. Dey, A.K.; Poddar, P.; Singh, K.K.; Sahoo, K.L. Mechanical and wear properties of rheocast and conventional. Mater. Sci. Eng. A 2006, 435-436, 521-529. [CrossRef]

103. Bayoumi, M.A.; Negm, M.I.; El-Gohry, A.M. Microstructure and mechanical properties of extruded Al-Si alloy (A356) in the semi-solid state. Mater. Des. 2009, 30, 4469-4477. [CrossRef]

104. Vencl, A.; Bobic, I.; Miskovic, Z. Effect of thixocasting and heat treatment on the tribological properties of hypoeutectic Al-Si alloy. Wear 2008, 264, 616-623. [CrossRef]

105. Midson, S.; Keist, J.; Svare, J. Semi-Solid Metal Processing of Aluminum Alloy A390. In Proceedings of the SAE 2002 World Congress, Detroit, MI, USA, 4-7 March 2002.

106. Birol, Y.; Birol, F. Wear properties of high-pressure die cast and thixoformed aluminium alloys for connecting rod applications in compressors. Wear 2008, 265, 590-597. [CrossRef]

107. Pola, A.; Montesano, L.; Gelfi, M.; Roberti, R. Semisolid processing of Al-Sn-Cu alloys for bearing applications. Solid State Phenom. 2012, 192, 562-568. [CrossRef]

108. Alhawari, K.S.; Omar, M.Z.; Ghazali, M.J.; Salleh, M.S.; Mohammed, M.N. Evaluation of the microstructure and dry sliding wear behaviour of thixoformed A319 aluminium alloy. Mater. Des. 2015, 76, 169-180. [CrossRef]

109. Alhawari, K.S.; Omar, M.Z.; Ghazali, M.J.; Salleh, M.S.; Mohammed, M.N. Dry sliding wear behaviour of thixoformed hypoeutectic Al-Si-Cu alloy with different amounts of magnesium. Compos. Interfaces 2016, 23, 519-531. [CrossRef]

110. Pola, A.; Montesano, L.; Sinagra, C.; Gelfi, M.; La Vecchia, G.M. Influence of globular microstructure on cavitation erosion resistance of aluminium alloys. Solid State Phenom. 2016, 256, 51-57. [CrossRef]

111. Pola, A.; Montesano, L.; Tocci, M.; La Vecchia, G.M. Influence of Ultrasound Treatment on Cavitation Erosion Resistance of AlSi7 Alloy. Materials 2017, 10, 256. [CrossRef] [PubMed]

112. Bastidas, J.M.; Forn, A.; Baile, M.T.; Polo, J.L. Pitting corrosion of A357 aluminium alloy. Mater. Corros. 2001, 52, 691-696. [CrossRef]

113. Arrabal, R.; Mingo, B.; Pardo, A.; Mohedano, M.; Matykina, E.; Rodríguez, I. Pitting corrosion of rheocast A356 aluminium alloy in 3.5wt.\% NaCl solution. Corros. Sci. 2013, 73, 342-355. [CrossRef]

114. Tahamtan, S.; Boostani, A.F. Quantitative analysis of pitting corrosion behavior of thixoformed A356 alloy in chloride medium using electrochemical techniques. Mater. Des. 2009, 30, 2483-2489. [CrossRef]

115. Tahamtan, A.; Tahamtan, S.; Boostani, A.F.; Nazemi, H. Pitting corrosion of thixoformed, rheocast and gravity cast A356-T6 alloy in chloride media. Corros. Eng. Sci. Technol. 2009, 44, 384-388. [CrossRef]

116. Arrighini, A.; Gelfi, M.; Pola, A.; Roberti, R. Effect of ultrasound treatment of AlSi5 liquid alloy on corrosion resistance. Mater. Corros. 2010, 61, 218-221. [CrossRef]

117. Masuku, E.P.; Möller, H.; Curle, U.A.; Pistorius, P.C.; Li, W. Influence of surface liquid segregation on corrosion behavior of semi-solid metal high pressure die cast aluminium alloys. Trans. Nonfeer. Met. Soc. China 2010, 20, s837-s841. [CrossRef]

118. Möller, H.; Masuku, E.P. The Influence of Liquid Surface Segregation on the Pitting Corrosion Behavior of SemiSolid Metal High Pressure Die Cast Alloy F357. Open Corros. J. 2009, 2, 216-220. [CrossRef]

119. Mingo, B.; Arrabal, R.; Pardo, A.; Matykina, E.; Skeldon, P. 3D study of intermetallics and their effect on the corrosion morphology of rheocast aluminium alloy. Mater. Charact. 2016, 112, 122-128. [CrossRef]

120. Forn, A.; Rupérezu, E.; Baile, M.T.; Campillo, M.; Menargues, S.; Espinosa, I. Corrosion behaviour of A380 aluminiun alloy by semi-solid rheocasting. In Proceedings of the 10 ESAFORM Conference on Material Forming, Zaragoza, Spain, 18-20 April 2007.

(C) 2018 by the authors. Licensee MDPI, Basel, Switzerland. This article is an open access article distributed under the terms and conditions of the Creative Commons Attribution (CC BY) license (http://creativecommons.org/licenses/by/4.0/). 